\title{
Seasonal Analysis of the Number of Aeropiles in Anocentor nitens (Neumann, 1897) (Acari: Ixodidae) from the State of Rio de Janeiro, Brazil
}

\author{
Gilberto Salles Gazêta/ ${ }^{+}$, Luciana Guerim, Marinete Amorim, \\ Nicolau Maués Serra-Freire
}

\author{
Laboratório de Ixodides, Departamento de Entomologia, Instituto Oswaldo Cruz-Fiocruz, Av. Brasil 4365, \\ 21045-900 Rio de Janeiro, RJ, Brasil
}

\begin{abstract}
Variation between aeropile numbers of the right and left peritrematic plate in male and female Anocentor nitens (Neumann, 1897) is reported from a site in Brazil. From January to December 1998, 146 males and 247 females of A. nitens were recovered from Equus caballus L. in Silva Jardim District, State of Rio de Janeiro. Asymmetry of numbers of aeropiles between right and left plates occurred in $83.6 \%$ of the males and $82.2 \%$ of the females. Differences in the number of aeropiles between the sexes were not significant. Quantitative variation of aeropiles was correlated to the period of recovery, with significant asymmetry detected in August-September and November-December, mainly in males. Results suggest an adaptation, especially in the male ticks, that expresses itself as greater variation in the number of aeropiles in some periods of the year.
\end{abstract}

Key words: Anocentor nitens - aeropiles - seasonal analysis - ticks

Lees (1948), Milne (1950) and Lees and Milne (1951), have shown the importance of microclimatic factors for the survival and behaviour of ticks. Comparative analysis of the same tick species in different habitats demonstrated the influence of environment factors on the biology and ethology of ixodidae (Lees 1947, 1948, Daniel et al. 1976, 1977, Kahl \& Knülle 1988, Harlan \& Foster 1990). Short et al. (1989) showed that there is variation in the behaviour and resistance of the phases of different ixodid species. Such variation was seasonal and related to microclimatic factors. Gazêta et al. (1995), studying the behaviour of engorged female ticks and eggs in adverse conditions, verified differences in the behaviour, survival rates, incubation period and hatchability of Amblyomma cajennense (Fabricius, 1787), Boophilus microplus (Canestrini, 1887) and Anocentor nitens, when submitted to $100 \%$ relative humidity of the air. This indicates differences in the adaptative capacity of such species. Needhan and Teel (1991), studying three species of Amblyomma Koch 1844 in the same habitat, verified their different capacity in resisting desiccation, with consequent variation in their adaptation to environmental changes.

${ }^{+}$Corresponding author. Fax: +55-21-590.3545. E-mail: gsgazeta@ioc.fiocruz.br

Received 2 May 2000

Accepted 18 April 2001
Sonenshine (1993) and Crosbie and Boyce (1998) have discussed the relationship between climate, hosts and tick physiology and seasonality in the Ixodidae. However, few works have related the morphological variations to such seasonality, especially in A. nitens. Serra-Freire and Miziara (1989) verified the influence of the host in the formation of the two-host life cycle, Serra-Freire (1987) and Serra-Freire and Ahid (1993) studied the anomalous behaviour of engorged female ticks in the non-parasitic phase, demonstrating biological variability evident without, however, relating this to morphological parameters. Literature is vague in the characterization of $A$. nitens regarding the number of aeropiles, there not being, in most works, a definition of this number. Borges et al. (1998) stated that the number of aeropiles in $A$. nitens is smaller than 20 and characteristic of the species when compared to the species of Dermacentor Koch, 1844, from the New World and of Rhipicephalus sanguineus Latreille, 1829. Equally, Gazêta and Serra-Freire (1996) observed the maximum range of 20 aeropiles in the peritrematic plate. They established a curve of normal distribution for A. nitens from the Southeast region from Brazil, when they related the number of aeropiles for peritrematic plate to the frequency of occurrence of this number. The authors concluded that there is variation in the number of aeropiles in A. nitens, between the sides of the idiosomes as well as between sexes of tick species, and that such variation indicates a possible dependence between the 
frequence of such an attribute and sample areas of origin. They suggested cline formation from the State of Minas Gerais towards the states of Rio de Janeiro and São Paulo, Brazil.

\section{MATERIALS AND METHODS}

Adult A. nitens were collected from Equus caballus, from the "Campus III" of the Universidade Grande Rio, Silva Jardim District, State of Rio de Janeiro, Brazil (Lat. 22 39'03' S, Long. $42^{\circ} 23^{\prime} 30^{\prime \prime}$ W, Alt. $35 \mathrm{~m}$ ). The removal of ticks took place at 30-day intervals, from January to December 1998. For each collection five horses were chosen at random. The tick specimens were contained in glass vials and transported to the Ixodides Laboratory, Entomology Department, Oswaldo Cruz Institute-Fiocruz. They were then killed in hot water $\left( \pm 70^{\circ} \mathrm{C}\right)$, dried in filter paper, examined through a stereomicroscope, selected as undamaged, identified according to the dichotomous key of Aragão and Fonseca (1961), fixed in $70^{\circ} \mathrm{GL}$ alcohol and analyzed according to the aeropile numbers of the left and right peritrematic plates. The measure of central tendency and dispersion of the data was assessed down limit, up limit, medium mode and standard deviation. Sta- tistical analysis was by the Student-test to the 5\% probability level.

\section{RESULTS}

The quantitative analysis of the aeropiles of 247 females and 146 males from $A$. nitens (Tables I, II) showed significant differences in the number of aeropiles by peritrematic plate in the male specimens. The comparison of the aeropiles number between the right and left sides of the same specimen revealed differences in 203 females $(82.2 \%)$ and 122 males (83.6\%) (Table III), however it was not significant when both sexes were compared. This asymmetry vary according to the months of the year, being significant in August, September, November and December. Only males suffered significant variation in these months.

\section{DISCUSSION}

Despite a broad geographical distribution, lack of parasitic specificity and its confirmed pathogenicity, A. nitens is not presented as a commonly studied species, especially related to its taxonomic parameters. Since the original description its anatomic structures have been little studied. Gazêta and Serra-Freire (1996) showed that only among

TABLE I

Statistical monthly parameters of the aeropile numbers in the peritrematic plates of female Anocentor nitens, in Silva Jardim District, Rio de Janeiro, Brazil

\begin{tabular}{|c|c|c|c|c|c|c|c|}
\hline Month & Side & $\mathrm{a}$ & A & Mo & $X$ & $\mathrm{~S}$ & $\Sigma \mathrm{x}$ \\
\hline & $\mathrm{R}$ & 7 & 30 & 9 & 12.40 & 5.66 & 372 \\
\hline \multirow[t]{2}{*}{ Jan } & $\mathrm{L}$ & 7 & 25 & 10 & 11.83 & 4.36 & 352 \\
\hline & $\mathrm{R}$ & 5 & 11 & 9 & 8.66 & 1.27 & 260 \\
\hline \multirow[t]{2}{*}{ Feb } & $\mathrm{L}$ & 6 & 11 & 9 & 8.60 & 1.30 & 258 \\
\hline & $\mathrm{R}$ & 7 & 13 & 8 & 9.03 & 1.32 & 271 \\
\hline \multirow[t]{2}{*}{ Mar } & $\mathrm{L}$ & 8 & 13 & 8,11 & 9.70 & 1.39 & 291 \\
\hline & $\mathrm{R}$ & 8 & 18 & 11 & 11.04 & 2.17 & 265 \\
\hline \multirow[t]{2}{*}{ Apr } & $\mathrm{L}$ & 7 & 18 & 10,11 & 10.87 & 2.32 & 261 \\
\hline & $\mathrm{R}$ & 9 & 19 & 12 & 13 & 2.57 & 248 \\
\hline \multirow[t]{2}{*}{ May } & $\mathrm{L}$ & 8 & 18 & 15 & 13.10 & 2.46 & 249 \\
\hline & $\mathrm{R}$ & 8 & 14 & 11 & 10.69 & 1.57 & 246 \\
\hline \multirow[t]{2}{*}{ Jun } & $\mathrm{L}$ & 8 & 15 & 11,12 & 11 & 1.67 & 253 \\
\hline & $\mathrm{R}$ & 8 & 14 & 11 & 11.39 & 1.59 & 319 \\
\hline \multirow[t]{2}{*}{ Jul } & $\mathrm{L}$ & 9 & 14 & 11,12 & 11.10 & 1.25 & 311 \\
\hline & $\mathrm{R}$ & 8 & 12 & 12 & 10.80 & 1.31 & 108 \\
\hline \multirow[t]{2}{*}{ Aug } & $\mathrm{L}$ & 7 & 13 & 10 & 9.90 & 1.52 & 99 \\
\hline & $\mathrm{R}$ & 8 & 15 & 9 & 10.33 & 2.12 & 155 \\
\hline \multirow[t]{2}{*}{ Sep } & $\mathrm{L}$ & 8 & 12 & 10 & 10 & 1.25 & 150 \\
\hline & $\mathrm{R}$ & 8 & 12 & 10 & 9.66 & 1.32 & 87 \\
\hline \multirow[t]{2}{*}{ Oct } & $\mathrm{L}$ & 8 & 13 & 10,13 & 10.88 & 1.90 & 98 \\
\hline & $\mathrm{R}$ & 7 & 12 & 9,11 & 9.88 & 1.53 & 89 \\
\hline \multirow[t]{2}{*}{ Nov } & $\mathrm{L}$ & 8 & 12 & 12 & 10.33 & 1.50 & 93 \\
\hline & $\mathrm{R}$ & 5 & 14 & 9 & 9.75 & 2.07 & 195 \\
\hline Dec & $\mathrm{L}$ & 6 & 17 & 8,9 & 9.55 & 2.58 & 191 \\
\hline
\end{tabular}

a: down limit; A: up limit; Mo: mode; X: mean; S: standard deviation; $\Sigma \mathrm{x}$ : aeropile numbers analyzed; R: right; L: left 
the ticks collected in Rio de Janeiro where the differences between males and females were significant considering the number of aeropiles. They considered it could be related to the physiographic characteristics of the region. The results of the present work support those of Gazêta and SerraFreire (1996), since they demonstrated significant differences between sexes. The fact that the males suffered such differences during the year seems to indicate an even larger influence of the environ-

TABLE II

Statistical monthly of the aeropile numbers in the peritrematic plates of male Anocentor nitens, in Silva Jardim District, Rio de Janeiro, Brazil

\begin{tabular}{|c|c|c|c|c|c|c|c|}
\hline Month & Side & $\mathrm{a}$ & A & Mo & $X$ & $\mathrm{~S}$ & $\Sigma \mathrm{x}$ \\
\hline & $\mathrm{R}$ & 8 & 9 & & 8.50 & 0.70 & 17 \\
\hline \multirow[t]{2}{*}{ Jan } & $\mathrm{L}$ & 8 & 8 & 8 & 8 & 0 & 16 \\
\hline & $\mathrm{R}$ & 6 & 10 & 8 & 8.20 & 1.09 & 246 \\
\hline \multirow[t]{2}{*}{ Feb } & $\mathrm{L}$ & 6 & 13 & 8 & 8.30 & 1.32 & 250 \\
\hline & $\mathrm{R}$ & 6 & 12 & 8 & 8.86 & 1.89 & 204 \\
\hline \multirow[t]{2}{*}{ Mar } & $\mathrm{L}$ & 7 & 13 & 8 & 9.47 & 1.78 & 218 \\
\hline & $\mathrm{R}$ & 8 & 13 & 8,11 & 10.20 & 1.79 & 113 \\
\hline \multirow[t]{2}{*}{ Apr } & $\mathrm{L}$ & 7 & 10 & 10 & 9.27 & 1 & 102 \\
\hline & $\mathrm{R}$ & 8 & 17 & $9,10,11$ & 12.26 & 2.81 & 184 \\
\hline \multirow[t]{2}{*}{ May } & $\mathrm{L}$ & 7 & 15 & $13,14,15$ & 11 & 2.47 & 165 \\
\hline & $\mathrm{R}$ & 9 & 13 & 10 & 11.10 & 1.37 & 111 \\
\hline \multirow[t]{2}{*}{ Jun } & $\mathrm{L}$ & 8 & 12 & 10,11 & 10.10 & 1.19 & 101 \\
\hline & $\mathrm{R}$ & 8 & 14 & 10 & 10.80 & 1.53 & 217 \\
\hline \multirow[t]{2}{*}{ Jul } & $\mathrm{L}$ & 8 & 13 & 10 & 10.50 & 1.50 & 210 \\
\hline & $\mathrm{R}$ & 7 & 11 & 8 & 8.80 & 1.64 & 44 \\
\hline \multirow[t]{2}{*}{ Aug } & $\mathrm{L}$ & 7 & 10 & 9 & 9 & 1.22 & 45 \\
\hline & $\mathrm{R}$ & 7 & 11 & 8,7 & 8 & 1.58 & 72 \\
\hline \multirow[t]{2}{*}{ Sep } & $\mathrm{L}$ & 8 & 10 & 9 & 8.88 & 0.78 & 80 \\
\hline & $\mathrm{R}$ & 7 & 11 & 10 & 9.28 & 1.38 & 65 \\
\hline \multirow[t]{2}{*}{ Oct } & $\mathrm{L}$ & 7 & 11 & 8,10 & 9 & 141 & 63 \\
\hline & $\mathrm{R}$ & 6 & 9 & 9 & 7.80 & 1.30 & 39 \\
\hline \multirow{2}{*}{ Nov } & $\mathrm{L}$ & 7 & 10 & 9 & 8.80 & 1.09 & 44 \\
\hline & $\mathrm{R}$ & 7 & 8 & 8 & 7.55 & 0.52 & 68 \\
\hline Dec & $\mathrm{L}$ & 6 & 10 & 9 & 8.33 & 1.41 & 75 \\
\hline
\end{tabular}

a: down limit; A: up limit; Mo: mode; X: mean; S: standard deviation; $\Sigma x$ : aeropile numbers analysed; R: right, L: left

TABLE III

Number and monthly percentage of specimens Anocentor nitens with asymmetric number of aeropiles in the peritrematic plate, collected from Equus caballus from January to December, 1998 in Silva Jardim District, Rio de Janeiro, Brazil

\begin{tabular}{|c|c|c|c|c|c|c|c|c|c|}
\hline \multirow[b]{3}{*}{ Month } & \multicolumn{3}{|c|}{ Males } & \multicolumn{3}{|c|}{ Females } & \multicolumn{3}{|c|}{ Total } \\
\hline & \multirow[b]{2}{*}{ No. collected } & \multicolumn{2}{|c|}{ Asymmetric } & \multirow[b]{2}{*}{ No. collected } & \multicolumn{2}{|c|}{ Asymmetric } & \multirow[b]{2}{*}{ No. collected } & \multicolumn{2}{|c|}{ Asymmetric } \\
\hline & & No. & $\%$ & & No. & $\%$ & & No. & $\%$ \\
\hline Jan & 2 & 1 & 50 & 30 & 23 & 76.7 & 32 & 24 & 75 \\
\hline Feb & 30 & 30 & 66.7 & 30 & 28 & 93.3 & 60 & 48 & 80 \\
\hline Mar & 23 & 19 & 82.6 & 30 & 22 & 73.3 & 53 & 41 & 77.4 \\
\hline Apr & 11 & 10 & 90.9 & 24 & 20 & 83.3 & 35 & 30 & 85.7 \\
\hline May & 15 & 15 & 100 & 19 & 16 & 84.2 & 34 & 31 & 91.2 \\
\hline Jun & 10 & 10 & 100 & 33 & 21 & 91.3 & 33 & 31 & 93.9 \\
\hline Jul & 20 & 17 & 85 & 28 & 23 & 82.14 & 48 & 40 & 83.3 \\
\hline Aug & 5 & 4 & 80 & 10 & 7 & 70 & 15 & 11 & 73.3 \\
\hline Sep & 9 & 9 & 100 & 15 & 13 & 86.6 & 24 & 22 & 91.7 \\
\hline Oct & 7 & 7 & 100 & 9 & 7 & 77.8 & 16 & 14 & 87.5 \\
\hline Nov & 5 & 2 & 40 & 9 & 9 & 100 & 14 & 11 & 78.6 \\
\hline Dec & 9 & 8 & 88.9 & 20 & 14 & 70 & 29 & 22 & 75.8 \\
\hline Total & 146 & 122 & 83.6 & 247 & 203 & 82.2 & 393 & 325 & 82.7 \\
\hline
\end{tabular}


ment variations on them. The finding that a larger amplitude, above 20 aeropiles in January for females (Table I), suggests morphological seasonality as a factor of sex-linked adaptation to the environmental variations.

Gazêta and Serra-Freire (1995) analyzed the variations in the number of the peritrematic plate of male and female A. nitens, verifying predominant asymmetry between the right and left sides. This confirms the results obtained, since $82.2 \%$ of females and $83.6 \%$ of males present asymmetry, showing no significant difference between males and females. There were, however, significant differences among males, indicating that they either present a larger capacity of phenotypical expression of this attribute or suffer larger pressure of environmental variations. Another important aspect of $A$. nitens asymmetry relies on the fact that significante variation takes place in August, Setember, November and December, indicating a possible climatic influence on males, since only males suffered significant variations in those months. Gazêta and Serra-Freire (1999), using A. nitens as a model, discuss the enzymatic method for the diagnosis of ixodid ticks. They concluded that samples must be obtained during the same period of the year for comparison of populations, since the phenotypical variations of enzymes could be more significant among periods of the year than among regions due to a mechanism of temporal survival.

The phenotypical seasonality or morphological and/or biochemical phenotypic parameters of ticks can clarify physiologically obscure aspects of the transport of bioagents, their resistance or adaptation capacity. The results obtained showed that the seasonal variation of the aeropiles number in A. nitens is an indication of the adaptative state, in Brazil, especially in the males that express a larger variation of this number in some periods of the year.

\section{REFERENCES}

Aragão HB, Fonseca F 1961. Notas de Ixodidae VIII. Lista e chave para os representantes da fauna ixodológica brasileira. Mem Inst Oswaldo Cruz 59: 115-129.

Borges LMF, Labruna MB, Linardi PM, Ribeiro MFB 1998. Recognition of the tick genus Anocentor Schulze, 1937 (Acari:Ixodidae) by numerical taxonomy. J Med Entomol 35: 891-894.

Crosbie PR, Boyce WM 1998. Dermacentor hunteri (Acari:Ixodidae): seasonal variation in questing adults and on-host feeding behavior of larvae and nymphs. J Med Entomol 35: 1034-1043.

Daniel M, Czerny V, Dusbabek E, Honzakova E, Olejnicek J 1976. Influence of microclimate on the life cycle of the common tick Ixodes ricinus (L.) in thermophilic oak forest. Fol Parasitol 23: 327-342.

Daniel M, Czerny V, Dusbabek E, Honzokova E, Olejnicek J 1977. Influence of microclimate on the life cycle of the common tick Ixodes ricinus (L.) in an open area in comparison with forest habitats. Fol Parasitol 24: 149-160.

Gazêta GS, Serra-Freire NM 1995. Anocentor nitens (Neumann, 1897) na região sudeste do Brasil: constatação da assimetria entre placas peritremáticas e reavaliação do caráter festões. $R$ Bras Med Vet 17: 21-25.

Gazêta GS, Serra-Freire NM 1996. Reavaliação dos caracteres da placa peritremática para diagnose de Anocentor nitens (Neumann, 1897) na região sudeste. Arq Bras Med Vet Zootec 48: 133-140.

Gazêta GS, Serra-Freire NM 1999. Avaliação e caracterização de método isoenzimático na determinação do zimodema de Anocentor nitens (Neumann, 1897) (Acari:Ixodidae). Entomol Vect 6: 721-734.

Gazêta GS, Rocha GC, Cavalcanti PL, Caiaffa RM, Serra-Freire NM 1995. Comportamento de teleóginas e ovos de Amblyomma cajennense, Anocentor nitens e Boophilus microplus em imersão. Entomol Vect 2: 145-150.

Harlan HJ, Foster WA 1990. Micrometeorologic factors affecting host seeking activity of adult Dermacentor variabilis (Acari:Ixodidae). J Med Entomol 27: 471-479.

Kahl O, Knulle W 1988. Water vapor uptake from subsaturated atmospheres by engorged immature ixodid ticks. Exp Appl Acarol 4: 73-83.

Lees AD 1947. Transpiration and the structure of epicuticule in ticks. J Exp Biol 25: 145-207.

Lees AD 1948. The sensory physiology of the sheep tick, Ixodes ricinus (L.). J Exp Biol 33: 379-410.

Lees AD, Milne A 1951. The seasonal and diurnal activities of individual sheep ticks (Ixodes ricinus L.). Parasitology 41: 189-209.

Milne A 1950. The ecology of the sheep tick, Ixodes ricinus L. Microhabitat economy of the adult tick. Parasitology 40: 14-34.

Needham GR, Teel PD 1991. Off-host physiological ecology of ixodid ticks. Ann Rev Entomol 36: 659-681.

Serra-Freire NM 1987. Comportamento exótico de teleóginas de Anocentor nitens (Neumann) (Acari: Ixodidae). Arq Flum Med Veter 2: 17-18.

Serra-Freire NM, Ahid SM 1993. Avaliação do comportamento anômalo de Anocentor nitens (Neumann) (Acari: Ixodidae), durante a fase não parasitária. Rev Bras Zool 10: 257-260.

Serra-Freire NM, Miziara SR 1989. Influência do hospedeiro no ciclo e comprovação do ciclo heteroxeno de Anocentor nitens (Neumann, 1897). Mem Inst Oswaldo Cruz 84: 213-218.

Short NJ, Floyd RB, Norval RAI, Sutherst RW 1989. Survival and behaviour of unfed stages of the ticks Rhipicephalus sanguineus, Boophilus decoloratus and $B$. microplus under field conditions in Zimbabwe. Exp Appl Acarol 6: 215-236.

Soneshine DE 1993. Biology of Ticks, Vol. 2, Oxford University Press, New York, 463 pp. 